\title{
Production and Metabolism of Indole Acetic Acid in Root Nodules and Symbiont (Rhizobium undicola) Isolated from Root Nodule of Aquatic Medicinal Legume Neptunia oleracea Lour.
}

\author{
Pallab Kumar Ghosh, ${ }^{1}$ Tarun Kumar De, ${ }^{2}$ and Tushar Kanti Maiti ${ }^{1}$ \\ ${ }^{1}$ Microbiology Laboratory, Department of Botany, Burdwan University, Burdwan, West Bengal 713104, India \\ ${ }^{2}$ Department of Marine Science, Calcutta University, 35 B.C. Road, Kolkata 700019, India \\ Correspondence should be addressed to Tushar Kanti Maiti; tkmbu@yahoo.co.in
}

Received 30 August 2014; Revised 21 November 2014; Accepted 11 December 2014

Academic Editor: Zed Rengel

Copyright (C) 2015 Pallab Kumar Ghosh et al. This is an open access article distributed under the Creative Commons Attribution License, which permits unrestricted use, distribution, and reproduction in any medium, provided the original work is properly cited.

\begin{abstract}
Indole acetic acid is a phytohormone which plays a vital role in plant growth and development. The purpose of this study was to shed some light on the production of IAA in roots, nodules, and symbionts of an aquatic legume Neptunia oleracea and its possible role in nodular symbiosis. The symbiont (N37) was isolated from nodules of this plant and identified as Rhizobium undicola based on biochemical characteristics, 16S rDNA sequence homology, and DNA-DNA hybridization results. The root nodules were found to contain more IAA and tryptophan than root; however, no detectable amount of IAA was found in root. The IAA metabolizing enzymes IAA oxidase, IAA peroxidase (E.C.1.11.1.7), and polyphenol oxidase (E.C.1.14.18.1) were higher in root than nodule but total phenol and IAA content were reversed. The strain N37 was found to produce copious amount of IAA in YEM broth medium with tryptophan and reached its stationary phase at $20 \mathrm{~h}$. An enrichment of the medium with mannitol, ammonium sulphate, $\mathrm{B}_{12}$, and 4-hydroxybenzaldehyde was found to promote the IAA production. The presence of IAA metabolizing enzymes and IAA production with PGPR traits including ACC deaminase activity of the symbionts was essential for plant microbe interaction and nodule function.
\end{abstract}

\section{Introduction}

There are over 19000 species of the family Fabaceae (Leguminosae) and this family was divided into three subfamilies [1], namely, Papilionoideae, Mimosoideae, and Caesalpinioideae. The majority of species ( $96 \%$ species of each) in the former two subfamilies formed nodule but relatively few $(22 \%)$ of the later are nodulated [2]. The symbiotic relationships of Rhizobia and legume plants were studied for over 100 years as mutualistic association. However, until 25 years ago, most of the legume nodulating bacteria (LNB) were identified as Rhizobium spp. The situation changed after the application of $16 \mathrm{~S}$ rDNA based bacterial identification on rhizobia as it was mandatory for bacterial species description [3], which led to the division of Rhizobia into the currently accepted many genera, namely, Azorhizobium, Bradyrhizobium, Mesorhizobium, Rhizobium, Allorhizobium, and Ensifer (Sinorhizobium) [4].

Most of the explored legumes are crop plants that are studied in relation to nitrogen fixation by the symbiont in root nodule. Besides nitrogen fixation, the root nodules of legume plants contained appreciable amount of IAA that are involved in genesis and development of nodules [5, 6]. Rhizobial nodule bacteria produced IAA, which plays an important role in plant growth and in legume-rhizobia interaction. Hunter [7] first reported the plant hormone production in nodules and its transport to the host by the nodular symbiont. The production of IAA by nodule bacteria from nodular tryptophan and its implication for nodule development are well-documented [8-10]. It was reported that IAA acts as a 
signal molecule which is involved in plant signal processing, motility, or attachment of bacteria in root which help in legume-Rhizobium symbiosis [11].

The IAA productions by the symbiont in nodules were investigated in some agricultural herb legumes [12-14], in shrubs $[8,10]$, or in some trees [15-17]. The IAA production of symbiont isolated from aquatic legume plants was not reported earlier. Neptunia oleracea is a tropical, annual, aquatic, and floating herb that belongs to the subfamily Mimosoideae of family Fabaceae. The plant has medicinal uses like treatment of chronic pain in abdomen, joint inflammation, anticancer, antioxidant, and antimicrobial properties [18].

In the present investigation, the symbiont isolated from the root nodules of aquatic legume Neptunia oleracea Lour. is designated as N37. The strain was identified as Rhizobium undicola based on 16S rDNA sequences based molecular phylogenetic approach. This study was to shed some light on the role of IAA metabolizing enzymes on IAA production in nodule of this plant. Attempts were also made to optimize the cultural conditions for IAA production and to shed some light on nodular IAA production for nodule function.

\section{Material and Methods}

2.1. Sources of Plant. The plant was collected from the waterlogged pond of village Koichor, District Burdwan, West Bengal, India, and identified as of Neptunia oleracea Lour.

2.2. Microorganism, Medium, and Growth Condition. The bacteroides were isolated from fresh, healthy, surface sterilized, and pink-colored root nodules of Neptunia oleracea Lour. and grown in pure culture. The medium selected for bacterial growth and IAA production was yeast extract mineral medium of Skerman [19] with 1\% mannitol (YEM) supplemented with L-tryptophan. The growth and production of IAA were measured turbidimetrically using a Shimadzu UVVIS double beam spectrophotometer (Model-190) at $540 \mathrm{~nm}$. The isolates produced the highest amount of IAA that was selected for further study.

2.3. Genomic DNA Extraction, PCR Amplification, and Sequencing of $16 S \mathrm{rDNA}$. For $16 \mathrm{~S}$ rDNA sequence analysis, DNA was isolated according to Sambrook and Russell [20]. The 16S rDNA of the strain N37 was amplified by using 5-GAGTTTGAT CCTGGCTCAG-3 (forward primer) and 5-AGAAAGGAGGTGATCCAGCC-3 (reverse primer). The amplification was performed with a Thermal Cycler, Model PCT-200 (M.J. Research, Waltham, MA, USA). After amplification, the PCR products were purified using the QIAQuick Gel Extraction Kit (Qiagen, Hilden, Germany) and sequenced using a CEQ dye terminator cycle sequencing kit in an automated DNA sequencer (Model CEQ 8000; Beckman Coulter, Fullerton, CA, USA). The nucleotide sequences obtained were assembled using the sequence alignment-editing program Bioedit (http://www.mbio.ncsu.edu/BioEdit/bioedit.html). The 16S rDNA sequence obtained was compared using the NCBI and
EzTaxon server. Phylogenetic tree was constructed according to the Kimura 2 parameter model [21] using the MEGA 5 software package.

2.4. DNA-DNA Homology Study. The DNA-DNA reassociation study was performed following the method of Ezaki et al. [22]. The hybridization study was conducted with the strain N37 with R. undicola strain LMG $11875^{\mathrm{T}}$ showing the highest $16 \mathrm{~S}$ rDNA sequence similarity (99.86\%). As negative control, DNA from E. coli strain HB101 was taken for this experiment [23].

2.5. Estimation of IAA Production in Culture. The medium was centrifuged and cell-free supernatant was used for IAA extraction according to Sinha and Basu [15]. The IAA was estimated in extract spectrophotometrically by Salkowski reagent $\left(0.5 \mathrm{M} \mathrm{FeCl}_{3} 1 \mathrm{~mL}\right.$ and $35 \%$ perchloric acid $\left.50 \mathrm{~mL}\right)$ following the method of Gordon and Weber [24].

2.6. Culture of the Symbiont. In cultural studies, different carbon sources were added separately to the tryptophan supplemented basal medium without mannitol. In order to check the maximum production of IAA, the medium was enriched with the supplements that individually increased the IAA production maximum. All the supplements used for cultural optimization were filter-sterilized through bacterial filter and were added to the medium aseptically.

2.7. Extraction and Estimation of Tryptophan, IAA, and Phenol. Tryptophan was extracted following Nitsch [25] and estimated spectrophotometrically at $360 \mathrm{~nm}$ following the method of Hassan [26]. IAA was extracted from fresh tissues of both the roots and the nodules of Neptunia oleracea following the method of Sinha and Basu [15] and was estimated spectrophotometrically by Salkowski reagent following of Gordon and Weber [24]. Total phenol content of the tissue was extracted and estimated following Bray and Thorpe [27].

2.8. IAA Oxidase, Peroxidase, and Polyphenol Oxidase Assay. The enzymes were assayed from the dialyzed extract of plant tissue. IAA oxidase was estimated following Sinha and Basu [15]. IAA peroxidase and polyphenol oxidase were estimated as described in Kar and Mishra [28]. Oxidation of IAA by peroxidase activity of the purified extract was estimated as described in Ghosh et al. [10]. The leftover IAA was estimated according to Gordon and Weber [24]. The protein content in the enzyme extract was estimated following Lowry et al. [29].

2.9. Plant Growth Promoting Traits of the Isolated Strain. The phosphate solubilization activity of the isolated strain was detected by the halo zone on Pikovskaya's agar plates [30] and inorganic phosphate solubilization was estimated in culture followed by Jackson [31]. Siderophore production was examined on chrome-azurol-S agar medium as described by Schwyn and Neilands [32] and estimated quantitatively in culture according to Payne [33]. The isolated strain was grown in $\mathrm{N}_{2}$-free Davis and Mingoli [34] medium for detection of 
$\mathrm{N}_{2}$ fixing ability. The plates were incubated at $30^{\circ} \mathrm{C}$ for 4 days and were observed daily for colony formation. The appearing colonies were reinoculated on the same medium and incubated under the same experimental conditions. The N37 strain and Rhizobium sp. P2 strain (HNO56031) (as positive control) are grown in nitrogen-free CS7 medium [35] and E. coli (as negative control) is grown in nutrient agar medium; the nitrogenase was estimated by acetylene reduction test using gas chromatography (VARIAN CP3800) fitted with flame ionization detector (FID) [36]. Extracellular polysaccharide of the cell-free supernatant was estimated by phenolsulphuric acid method, following Dubois et al. [37]. The 1aminocyclopropane-1-carboxylate (ACC) deaminase activities of the isolated strain N37 were qualitatively measured in agar plate by Glick et al. [38]. The bacteria were inoculated onto agar plates containing modified M9 medium $(5.8 \mathrm{~g} / \mathrm{L}$ $\mathrm{Na}_{2} \mathrm{HPO}_{4} ; 3 \mathrm{~g} / \mathrm{L} \mathrm{KH}_{2} \mathrm{PO}_{4} ; 0.5 \mathrm{~g} / \mathrm{L} \mathrm{NaCl}$; supplemented with $0.25 \mathrm{mM} \mathrm{CaCl}_{2} ; 1 \mathrm{mM} \mathrm{MgSO}_{4}$; and $0.3 \mathrm{~g} / \mathrm{mL}$ biotin) devoid of nitrogen and carbon sources but supplemented with ACC at $5.0 \mathrm{~g} / \mathrm{L}$. The plates were incubated at $30^{\circ} \mathrm{C}$ for 4 days and were observed daily for colony formation. Colonies produced were reinoculated in the same media and incubated under the same experimental conditions. The newly formed colonies on modified M9 medium supplemented with ACC were considered positive for ACC deaminase activity. Carbonand nitrogen-free M9 medium without ACC supplement was used as control, in which no colony appeared after 10 days. The quantitative estimation of ACC deaminase enzyme activity was assayed according to a modification of the method of Honma and Shimomura [39], which measures the amount of $\alpha$-ketobutyrate produced when the ACC deaminase cleaves ACC. The amount of $\alpha$-ketobutyrate generated by this reaction was determined by comparing the absorbance at $540 \mathrm{~nm}$ of a sample to a standard curve of $\alpha$ ketobutyrate. One unit of ACC deaminase activity indicated the formation of $1 \mathrm{nmol}$ of $\alpha$-ketobutyrate per mg protein per hour under these conditions. The protein content in the enzyme extract was estimated following Lowry et al. [29].

2.10. Statistical Analysis. Values are the mean \pm SEM of 3 replicates. All data were subjected to Student's $t$-test analysis with significance level of $P<0.05$ using SPSS software package. The statistical analyses [40] were performed using the SPSS version 11 software [41] using 3 replicates. It was performed by using a two-way factorial ANOVA. In all cases, linearly independent pairwise comparison was carried out to determine the significant differences within the variables.

\section{Results and Discussion}

3.1. Study of Plant Morphology and Physical Parameters in Plant Habitat. Neptunia oleracea Lour. is an aquatic legume commonly known as water sensitive plant or water mimosa grown in a pond of Burdwan district. It has numerous white spongy air filled tissues that cover the stem, which helps the plant for buoyancy in water. The buoyant floating stems and adventitious roots arising from nodes possessed numerous root nodules. Nodules were small aggregated, deep pink in color, mostly elongated to oval shape sometimes branch. The plant is distributed in Africa, tropical Asia, Australia, and America. The plant prefers to grow in rainy season but when the water level falls during the dry season, the plants often perish [42].

\subsection{Content of IAA, Tryptophan, and Phenol in Root and} Nodule. The healthy mature nodules of Neptunia oleracea were found to contain higher amount of IAA $(7 \mu \mathrm{g} / \mathrm{g})$ but the amount of IAA was not detected in the root (Table 1). However, the roots also contained a detectable amount of tryptophan though it was considerably less than the nodules (Table 1). Phenol content was also higher in the nodules than roots (Table 2). Similarly, the IAA content was found to be higher in nodules than root of other legumes where it was below the level of detection $[8,12]$. The high tryptophan pool in the nodule was utilized for synthesis of higher amount of IAA that might have helped in legume-Rhizobium symbiosis $[11,13]$.

3.3. Activity of IAA Metabolizing Enzymes in Root and Nodule. IAA metabolizing enzymes such as IAA oxidase and peroxidase (EC1.11.1.7) and polyphenol oxidase (E.C.1.14.18.1) were estimated in root and nodule. The level IAA catabolizing enzymes such as IAA oxidase and peroxidase were found to be higher in root compared to nodule (Tables 1 and 2). Higher level of these enzymes in the roots might be a cause of the nondetectable amount of IAA in the roots. These enzymes were also higher in root compared to nodule as reported by Ghosh and Basu [9] and Ghosh et al. [10]. It could be suggested that IAA level was maintained within the nodule at physiologically higher concentration by these enzymes. Phenol content was also found to be higher in the nodules than roots. The peroxidase and polyphenol oxidase enzyme were more active in the root than nodules (Table 2). The higher level of total phenol in the nodules might have resulted from lower polyphenol oxidase activities in the nodule than in the roots (Table 2). The extracted phenols might be monohydroxy phenols, which are reported to promote IAA oxidase activity [43], and these could explain the lesser amount or nondetectable amount of IAA in the roots of this plant. Variation in the synthesis of phenols in different tissues by phenylalanine ammonia lyase and tyrosine ammonia lyase [44] would also cause differences of phenol levels.

3.4. Isolation, Characterization, and Identification of Symbiont. Five bacterial strains were isolated from the healthy nodules of Neptunia oleracea, among which the N37 was finally screened based on IAA production abilities in YEM medium supplemented with L-tryptophan (Table 3). Isolated strain was found to be gram negative, nonspore forming aerobic bacteria. Phylogenetic analysis was carried out with 16S rDNA sequences of type strains of Rhizobium spp. with maximum sequence similarity with our strain obtained from NCBI blast result and EZ taxon. Besides, two other bacteria, namely, Labrys neptunia Liujia-146 (NR043801) and Devosia neptuniae J1 (AF469072), are also taken into consideration for preparation of phylogenetic tree as these bacteria are also 
TABLE 1: Contents of tryptophan, IAA, IAA oxidase, and IAA peroxidase in nodules and roots of Neptunia oleracea (Lour.). Results presented are the mean of 3 individual replicates. ND $=$ not detected.

\begin{tabular}{|c|c|c|c|c|}
\hline Plant parts & $\begin{array}{c}\text { IAA } \\
(\mu \mathrm{g} / \mathrm{g} \text { fresh tissue })\end{array}$ & $\begin{array}{c}\text { Tryptophan } \\
(\mu \mathrm{g} / \mathrm{g} \text { fresh tissue })\end{array}$ & $\begin{array}{c}\text { IAA oxidase } \\
(\mu \mathrm{g} \text { of IAA oxidase/mg } \\
\text { protein } / \mathrm{h})\end{array}$ & $\begin{array}{c}\text { IAA peroxidase } \\
(\mu \mathrm{g} \text { of IAA oxidase/mg } \\
\text { protein } / \mathrm{h})\end{array}$ \\
\hline Roots & ND & $420.0 \pm 0.88$ & $125.80 \pm 0.44$ & $38.77 \pm 0.21$ \\
\hline Nodule & $7.0 \pm 0.20$ & $1086.0 \pm 1.45$ & $20.40 \pm 0.11$ & $10.07 \pm 0.06$ \\
\hline
\end{tabular}

TABLE 2: Content of total phenol level, peroxidase, and polyphenoloxidase activities in root and nodule of Neptunia oleracea (Lour.). Results presented are the mean of 3 individual replicates.

\begin{tabular}{lccc}
\hline Plant parts & $\begin{array}{c}\text { Total phenol } \\
(\mu \mathrm{g} / \mathrm{g} \text { fresh tissue })\end{array}$ & $\begin{array}{c}\text { Peroxidase } \\
(\mu \mathrm{g} \text { purpurogallin } \\
\text { formed/min./mg protein })\end{array}$ & $\begin{array}{c}\text { Polyphenoloxidase } \\
(\mu \mathrm{g} \text { purpurogallin } \\
\text { formed/min./mg protein })\end{array}$ \\
\hline Nodule & $1035.0 \pm 2.08$ & $7.16 \pm 0.02$ & $11.7 \pm 0.04$ \\
Root & $720.0 \pm 1.15$ & $16.56 \pm 0.05$ & $23.8 \pm 0.05$ \\
\hline
\end{tabular}

TABLE 3: IAA production by different isolates obtained from the nodules of $N$. oleracea. Results presented are the mean of 3 individual experimental setups.

\begin{tabular}{llcc}
\hline Isolated strain & Host plant & Growth OD at 540 nm & $\begin{array}{c}\text { Production of IAA } \\
(\mu \mathrm{g} / \mathrm{mL})\end{array}$ \\
\hline Rhizobium undicola strain N30 & Neptunia oleracea Lour. & $1.24 \pm 0.01$ & $152.0 \pm 0.52$ \\
Rhizobium undicola strain N32 & Neptunia oleracea Lour. & $1.40 \pm 0.02$ & $148.0 \pm 0.66$ \\
Rhizobium undicola strain N34 & Neptunia oleracea Lour. & $1.56 \pm 0.01$ & $167.0 \pm 0.88$ \\
Rhizobium undicola strain N35 & Neptunia oleracea Lour. & $1.62 \pm 0.03$ & $163.0 \pm 0.88$ \\
Rhizobium undicola strain N37 & Neptunia oleracea Lour. & $1.99 \pm 0.02$ & $226.0 \pm 1.54$ \\
\hline
\end{tabular}

The bacteria were grown in L-tryptophan (0.1\%) supplemented yeast extract medium for $24 \mathrm{~h}$ at $30 \pm 2^{\circ} \mathrm{C}$. The control set was devoid of any carbon sources.

isolated from the nodule of this plant $[45,46]$. As evident from phylogenetic tree (Figure 1), the strain N37 formed a distinct separate cluster with Rhizobium undicola LMG 11875T (Y17047) (= Allorhizobium undicola) [47]. The strain N37 was shown closest to $16 \mathrm{~S}$ rDNA with sequence similarity of $99.86 \%$ and $85 \%$ similarity of DNA-DNA hybridization result with the type strains Rhizobium undicola LMG 11875T (Y17047). The 16S rDNA sequence of N37 was deposited to NCBI and the sequence accession number is KF309665. The strain N37 was also deposited to Microbial Type Culture Collection (MTCC) and strain accession number is Rhizobium undicola MTCC12262. Thus the strain N37 isolated from the root nodule of this aquatic mimosoid legume was identified as Rhizobium undicola based on biochemical characteristics, 16S rDNA sequence homology (99.86\%), and (85\%) whole genome sequence relatedness [23].

3.5. Optimization of Cultural Requirements for IAA Production. The IAA producing ability of the isolated symbiont (identified as $R$. undicola) was tested in tryptophan supplemented by YEM medium. It was observed that both growth and IAA production of the strain N37 started simultaneously and reached the stationary phase after $20 \mathrm{~h}$ at $30 \pm 2^{\circ} \mathrm{C}$ (Figure 2(a)). Level of IAA production in the medium was declined during late stationary phase of growth. The bacteria preferred L-tryptophan for growth and IAA production than D-tryptophan and DL-tryptophan (data not shown). Although an increase in the concentration of L-tryptophan was found to enhance growth and IAA production by this N37 strain (Figure 2(b)), it appeared that when concentration of L-tryptophan exceeded $2 \mathrm{mg} / \mathrm{mL}$ in the medium it inhibited both the growth and IAA production.

Replacement of mannitol from the basal YEM medium by one of eight different carbon sources revealed that the strain N37 could utilize all the compounds for growth and IAA production (Table 4). The maximum growth and IAA production $(250 \mu \mathrm{g} / \mathrm{mL})$ were obtained with mannitol at $1 \%$ level (Figure 2(c)). The optimum concentrations of carbon sources as mannitol for IAA production were also reported by different Rhizobium spp. ranging from 1.0 to $1.5 \%[13,16]$. The key role of the carbon sources in the rhizobial IAA production was also reported by Datta and Basu [8] and Ghosh and Basu $[12,13]$. In Table 4 , the one-way ANOVA revealed significant differences in growth for different carbon sources (between carbon sources, CS: $F(1) 7,24=0.745 ; P<0.01)$ and no significant differences were observed in their interactions. The significant differences were observed in production of IAA for different carbon sources (between carbon sources, CS: $F(1) 7,24=7508.089 ; P<0.01)$.

Growth and IAA production by this strain were found to influence different inorganic and organic nitrogen sources (Table 5), among which ammonium sulphate at $0.3 \%$ was 


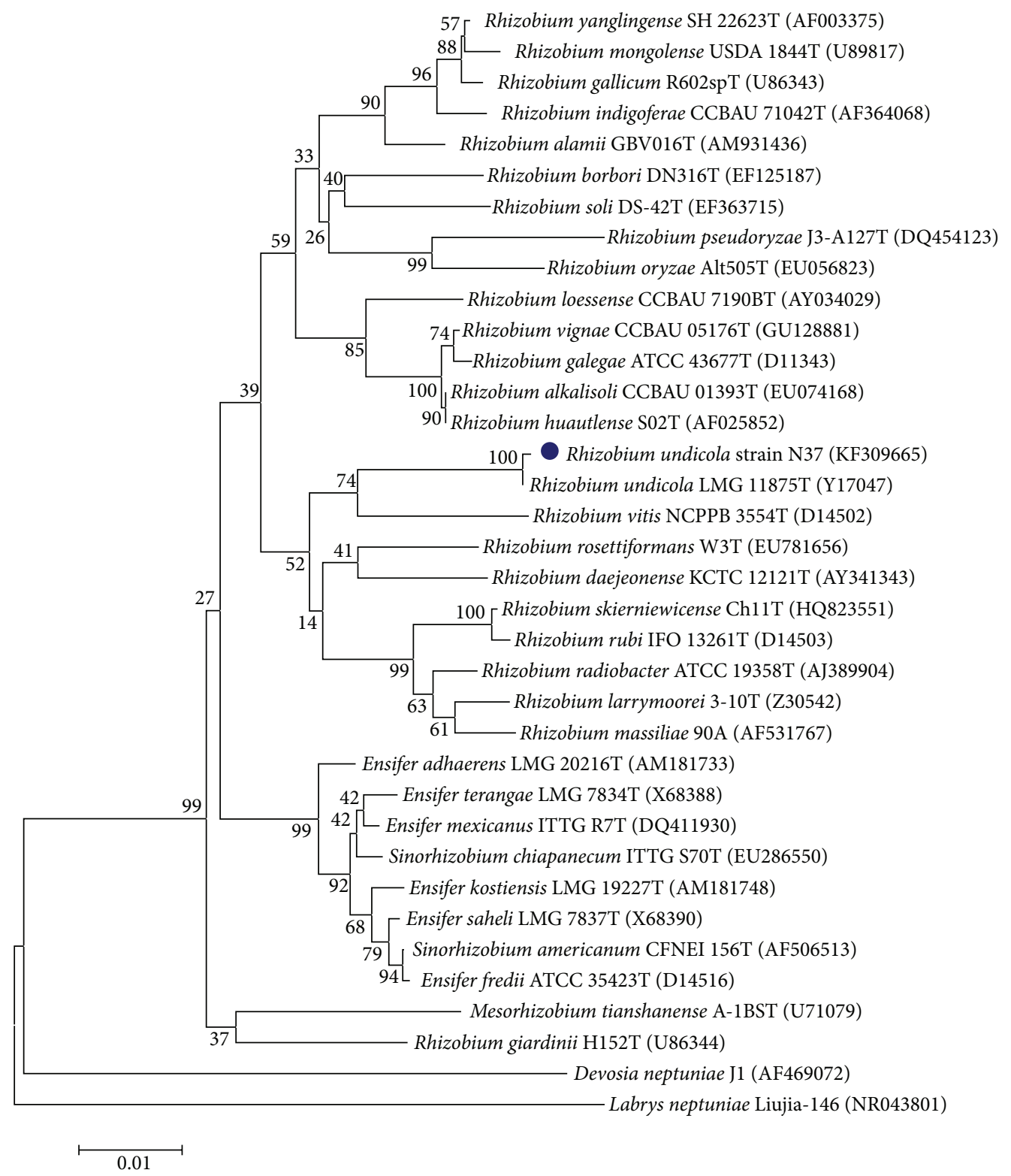

FIGURE 1: Phylogenetic tree was constructed using the neighbor-joining method based on the Kimura 2 parameter model by using MEGA 5 software. Significant bootstraps values (from 1000 replications) are indicated as percentages at the nodes. The scale bar indicates 0.01 fixed substitution per nucleotide position. Sequence accession numbers are indicated in parentheses.

found to be the most effective for growth and IAA production (Figure 2(d)). Jordan [48] and Vincent [49] reported that Rhizobium spp. could utilize several nitrogen compounds for growth, which might have responsibility for the increased IAA production. Nitrate was less preferred, but glutamine, glutamate, or $\mathrm{NH}_{4}{ }^{+}$was generally preferred nitrogen source for some strains of Rhizobium spp. [50]. Similarly, $\mathrm{NH}_{4}^{+}$was also preferred nitrogen source for this strain. In Table 5, the one-way ANOVA revealed significant differences in growth for different nitrogen sources (between nitrogen sources, NS: $F(1) 7,24=116.743 ; P<0.01)$ but no significant differences were observed in their interactions. The significant differences were observed in IAA production for different nitrogen sources (between nitrogen sources, NS: $F(1) 7,24=997.377$; $P<0.01)$.

Different degrees of growth enhancement of the bacteria by the vitamins suggested that the organism required a number of vitamins as cofactors [49]. Jordan [48] reported that biotin and other water soluble vitamins were required for growth of Rhizobium spp. Different legume nodulating rhizobial strains preferred different vitamins sources for IAA production reported by Chakrabarti et al. [50]; Datta and Basu [8]; Ghosh et al. [13]. Effect of vitamin on IAA production by this strain showed that $\mathrm{B}_{12}$ at $2 \mu \mathrm{g} / \mathrm{mL}$ was found to be the most effective (Table 6; Figure 3(a)). In Table 6, the one-way ANOVA revealed significant differences 


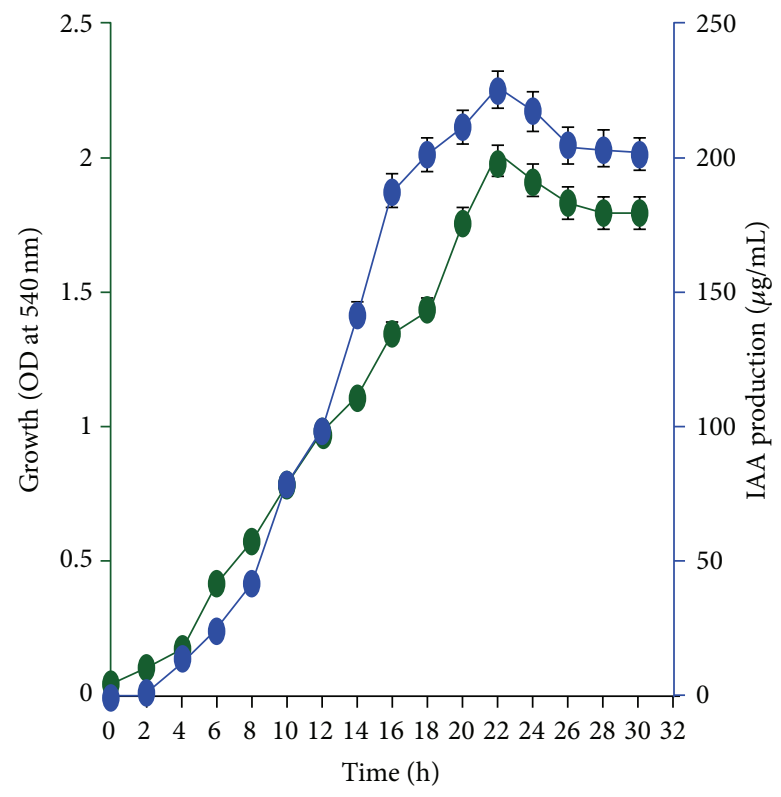

(a)

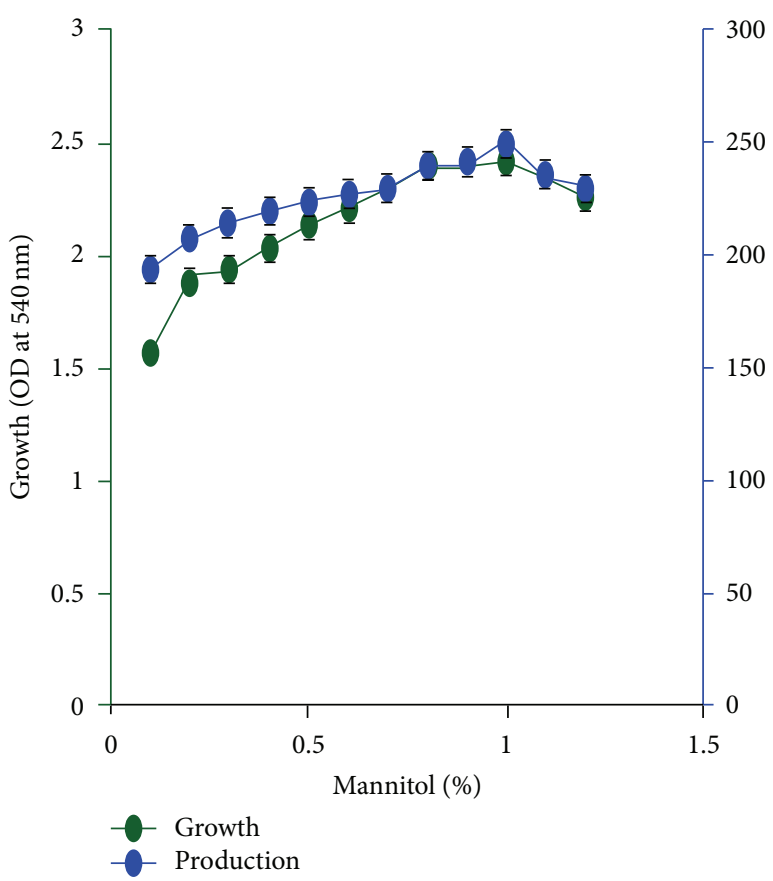

(c)

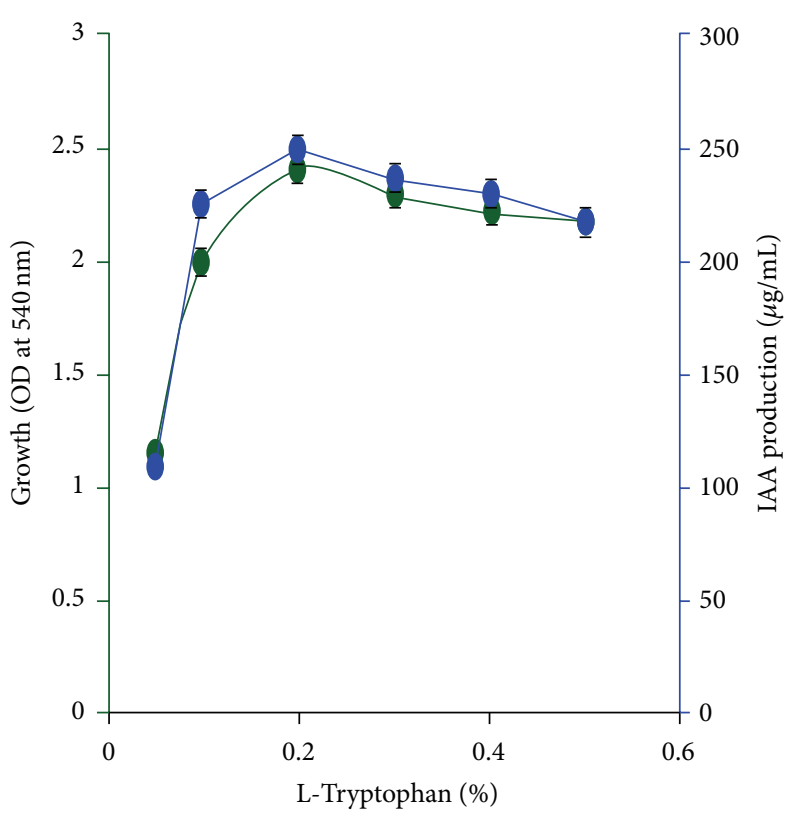

(b)

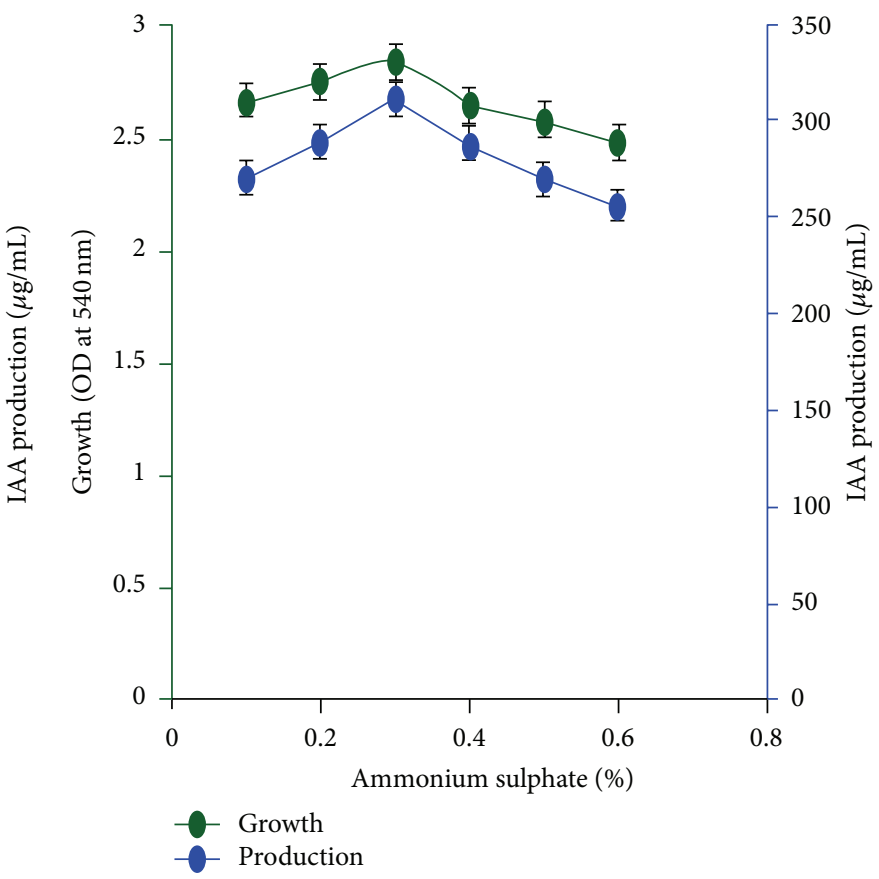

(d)

FIGURE 2: (a) Growth curve with IAA production. (b) Effect of different concentration of L-tryptophan (in \%). (c) Effect of different concentration of mannitol (in \%). (d) Effect of different concentration of ammonium sulphate (in \%). The bacteria were grown in yeast extract mineral medium for $24 \mathrm{~h}$ at $30 \pm 2^{\circ} \mathrm{C}$. $y$-axis bar shows standard error.

in growth for different vitamin sources (between vitamin sources, VS: $F(1) 5,18=118.778 ; P<0.01)$ and no significant differences were observed in their interactions. The significant differences were observed in indole acetic acid production for different vitamin sources (between vitamin sources, VS: $F(1) 5,18=916.040 ; P<0.01$ ).

It had been observed that some phenolic acids stimulated IAA production in symbionts (Rhizobium sp.) of certain legume plants [14]. So, the effect of different phenolic acids on IAA production was evaluated in culture by the isolated symbiont (Table 7). It was observed that 4-hydroxybenzaldehyde was found to be the best stimulant for bacterial growth and IAA production at a concentration of $1 \mu \mathrm{g} / \mathrm{mL}$ (Figure 3(b)). In Table 7 , the one-way ANOVA revealed significant differences in growth for different phenolic sources (between phenolic sources, PS: $F(1) 4,15=94.279 ; P<0.01)$ and 


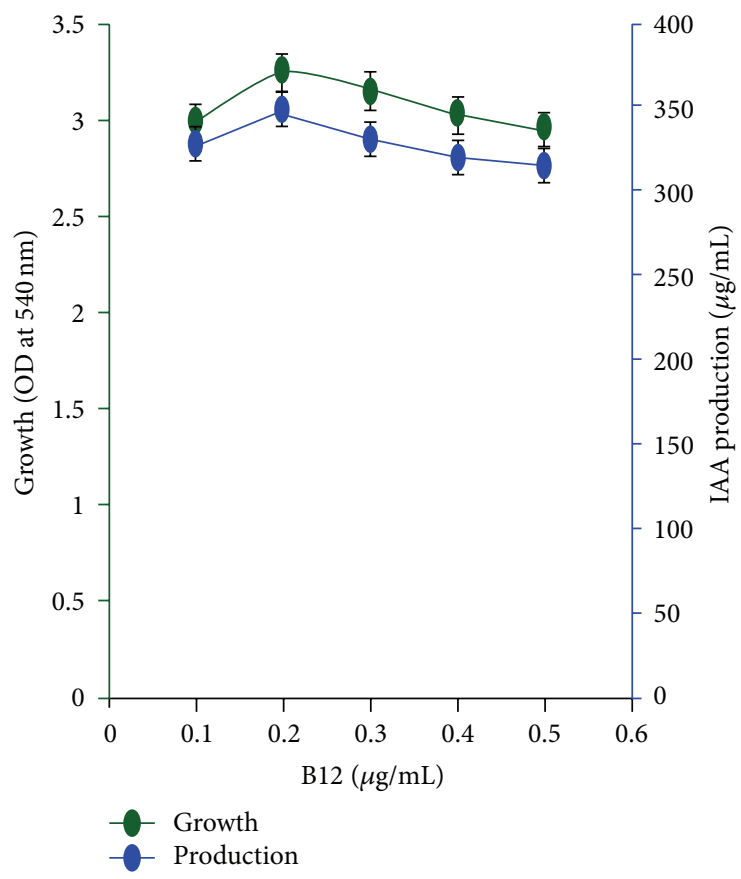

(a)

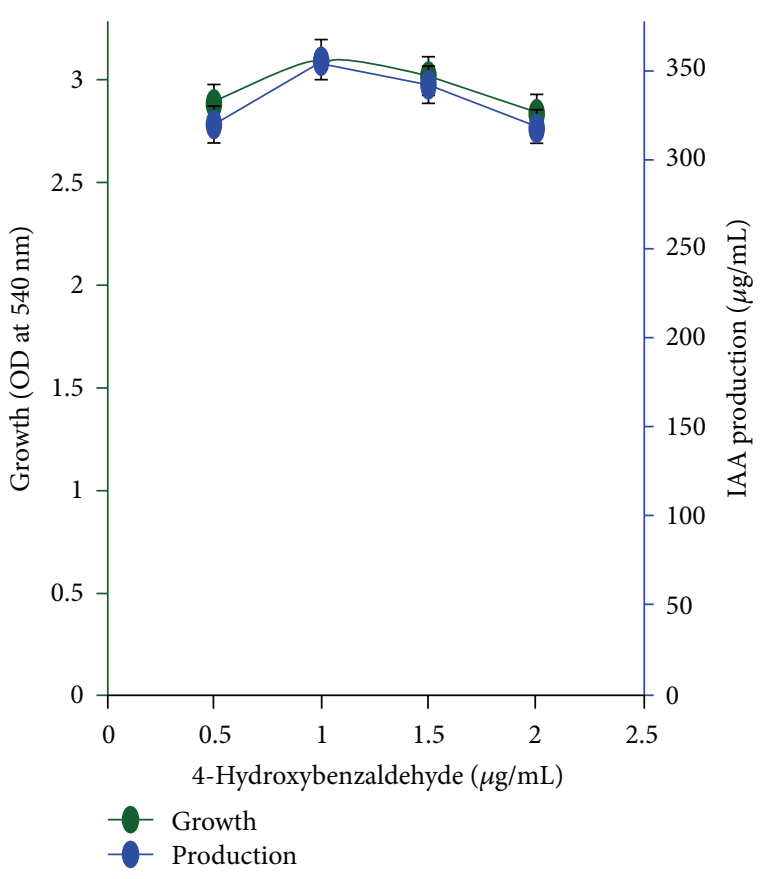

(b)

Figure 3: (a) Effect of different concentration of vitamin $\mathrm{B}_{12}$ (in $\mu \mathrm{g} / \mathrm{mL}$ ). (b) Effect of different concentration of 4-hydroxybenzaldehyde (in $\mu \mathrm{g} / \mathrm{mL})$. The bacteria were grown in yeast extract mineral medium for $24 \mathrm{~h}$ at $30 \pm 2^{\circ} \mathrm{C} . y$-axis bar shows standard error.

TABLE 4: Effect of different carbon sources on growth and IAA production by the Rhizobium undicola isolated from nodule of Neptunia oleracea (Lour.). The pairwise comparison showed significant differences under different carbon sources, growth, and indole acetic acid production of both the strains except those presented with NS (nonsignificant) in superscript. Here fructose and maltose for growth are nonsignificant (NS).

\begin{tabular}{lcc}
\hline Carbon sources $(0.2 \%)$ & $\begin{array}{c}\text { Growth at } \\
540 \mathrm{~nm}\end{array}$ & $\begin{array}{c}\text { IAA production } \\
(\mu \mathrm{g} / \mathrm{mL})\end{array}$ \\
\hline Control & $1.16 \pm 0.023$ & $55.0 \pm 0.33$ \\
Mannose & $1.32 \pm 0.011$ & $60.0 \pm 0.57$ \\
Lactose & $0.92 \pm 0.005$ & $82.0 \pm 0.66$ \\
Fructose ${ }^{\mathrm{NS}}$ & $1.12 \pm 0.005$ & $90.0 \pm 1.15$ \\
Sucrose $^{\mathrm{N}}$ & $1.02 \pm 0.008$ & $93.0 \pm 0.52$ \\
Maltose & $1.12 \pm 0.005$ & $122.0 \pm 0.66$ \\
Galactose & $1.56 \pm 0.012$ & $140.0 \pm 0.52$ \\
Glucose & $2.37 \pm 0.003$ & $172.0 \pm 1.15$ \\
Mannitol & $1.88 \pm 0.011$ & $208.0 \pm 1.45$ \\
\hline
\end{tabular}

The bacteria were grown in L-tryptophan $(0.2 \%)$ supplemented yeast extract medium for $24 \mathrm{~h}$ at $30 \pm 2^{\circ} \mathrm{C}$. The control set was devoid of any carbon sources. In others carbon sources were supplemented at $0.2 \%$ level individually. Results presented are the mean of 3 individual experimental setups.

no significant differences were observed in their interactions. The significant differences were observed in IAA production for different phenolic sources (between phenolic sources, PS: $F(1) 4,15=305.473 ; P<0.01)$.
TABLE 5: Effect of different nitrogen sources on growth and IAA production by the Rhizobium undicola isolated from nodule of Neptunia oleracea (Lour.). The pairwise comparison showed significant difference under different nitrogen sources, growth, and indole acetic acid production of the strain N37 and between their interactions.

\begin{tabular}{lcc}
\hline $\begin{array}{l}\text { Nitrogen sources } \\
(0.1 \%)\end{array}$ & $\begin{array}{c}\text { Growth OD at } \\
540 \mathrm{~nm}\end{array}$ & $\begin{array}{c}\text { IAA production } \\
(\mu \mathrm{g} / \mathrm{mL})\end{array}$ \\
\hline Control & $1.88 \pm 0.011$ & $208.0 \pm 1.45$ \\
$\mathrm{NH}_{4} \mathrm{Cl}$ & $2.02 \pm 0.005$ & $96.3 \pm 0.57$ \\
$\mathrm{NH}_{4} \mathrm{NO}_{3}$ & $1.97 \pm 0.008$ & $93.6 \pm 0.33$ \\
L-Asparagine & $2.35 \pm 0.005$ & $102.0 \pm 1.15$ \\
L-Glutamic acid & $2.52 \pm 0.008$ & $158.8 \pm 1.45$ \\
Glycine & $1.53 \pm 0.003$ & $103.8 \pm 0.66$ \\
Potassium nitrate & $2.22 \pm 0.005$ & $158.8 \pm 1.45$ \\
Arginine & $2.17 \pm 0.012$ & $159.3 \pm 1.15$ \\
monohydrochloride & $2.67 \pm 0.008$ & $271.0 \pm 0.52$ \\
$\left(\mathrm{NH}_{4}\right)_{2} \mathrm{SO}_{4}$ &
\end{tabular}

The bacteria were grown in yeast extract medium with $1 \%$ mannitol and Ltryptophan $(0.2 \%)$. The nitrogen sources were supplemented at $0.1 \%$ level individually in the experimental sets for $24 \mathrm{~h}$ at $30 \pm 2^{\circ} \mathrm{C}$. Results presented are the mean of 3 individual experimental setups.

The production of IAA by nodule bacteria from nodular tryptophan and its implication for nodule development were well documented $[9,51]$. Regulation of nodule development was achieved by control of auxin synthesis in nodule via indole 3-pyruvic acid pathway [52]. Flavonoid, inhibitors 
TABLE 6: Effect of different vitamins sources on growth and IAA production by the Rhizobium undicola isolated from nodule of Neptunia oleracea (Lour.). The pairwise comparison showed significant difference under different vitamin sources, growth, and indole acetic acid production of the strain N37 and between their interactions.

\begin{tabular}{lcc}
\hline Vitamins $(1 \mu \mathrm{g} / \mathrm{mL})$ & $\begin{array}{c}\text { Growth OD at } \\
540 \mathrm{~nm}\end{array}$ & $\begin{array}{c}\text { IAA production } \\
(\mu \mathrm{g} / \mathrm{mL})\end{array}$ \\
\hline Control & $1.88 \pm 0.011$ & $208.0 \pm 1.45$ \\
Riboflavin & $2.10 \pm 0.008$ & $172.8 \pm 0.96$ \\
Thiamin hydrochloride & $2.30 \pm 0.008$ & $173.0 \pm 0.88$ \\
Biotin & $2.55 \pm 0.020$ & $244.8 \pm 0.52$ \\
Nicotinic acid & $2.02 \pm 0.011$ & $217.8 \pm 0.88$ \\
L-Ascorbic acid & $2.22 \pm 0.011$ & $202.5 \pm 0.88$ \\
$\mathrm{~B}_{12}$ & $2.98 \pm 0.01$ & $328.0 \pm 1.00$ \\
\hline
\end{tabular}

The bacteria were grown in yeast extract medium with $1 \%$ mannitol, Ltryptophan $(0.2 \%)$, and ammonium sulphate $(0.3 \%)$. The vitamin sources were supplemented at $1(\mu \mathrm{g} / \mathrm{mL})$ level individually in the experimental sets for $24 \mathrm{~h}$ at $30 \pm 2^{\circ} \mathrm{C}$. Results presented are the mean of 3 individual experimental setups.

TABLE 7: Effect of phenolic acids on growth and IAA production by the strain Rhizobium undicola with the most effective supplements. The pairwise comparison showed significant difference under different phenolic compounds, growth, and indole acetic acid production of the strain N37 and between their interactions.

\begin{tabular}{lcc}
\hline Phenolic acid $(0.5 \mu \mathrm{g} / \mathrm{mL})$ & $\begin{array}{c}\text { Growth OD at } \\
540 \mathrm{~nm}\end{array}$ & $\begin{array}{c}\text { IAA production } \\
(\mu \mathrm{g} / \mathrm{mL})\end{array}$ \\
\hline Control & $2.47 \pm 0.01$ & $216.0 \pm 2.90$ \\
Salicylic acid & $2.87 \pm 0.02$ & $265.0 \pm 1.45$ \\
Catechuic acid & $2.44 \pm 0.01$ & $233.0 \pm 0.88$ \\
Gallic acid & $2.30 \pm 0.05$ & $206.0 \pm 2.64$ \\
4-Hydroxybenzaldehyde & $3.05 \pm 0.01$ & $322.0 \pm 1.15$ \\
Ferulic acid & $2.64 \pm 0.05$ & $272.0 \pm 0.57$ \\
\hline
\end{tabular}

The vitamin sources were supplemented at $1(\mu \mathrm{g} / \mathrm{mL})$ level individually in the experimental sets for $24 \mathrm{~h}$ at $30 \pm 2^{\circ} \mathrm{C}$. Results presented are the mean of 3 individual experimental setups.

of auxin transport, and auxin breakdown have also been suggested to induce nodulation and regulate nodule organogenesis [53]; it is likely that phenolic acid also induced nodulation in the similar way $[14,54]$. Phenolic acids from plant root exudates were known to play multifunctional roles in rhizospheric plant-microbe interaction. Some microbial phenolics are found to be responsible for defense mechanism and act as key signaling molecules. It has been observed that some phenolic acids, namely, protocatechuic acid, 4hydroxybenzaldehyde, and p-coumaric acid, are other phenolic acids influenced rhizobial growth and stimulated IAA production in Vigna mungo that regulate nodule morphogenesis [14]. A range of soluble and conjugated phenolic acids involved in bacterial defense and nodule development have been reported in Arachis hypogaea [54]. The present strain was also shown to stimulate IAA production by 4hydroxybenzaldehyde in culture. Phenolic acid might also exert its effect on IAA production like flavonoid by inhibiting or activating the IAA degrading enzymes. Moreover, phenolic
TABLE 8: Plant growth promoting attributes of the Rhizobium undicola strain N37. Results presented are the mean of 3 individual experimental setups.

\begin{tabular}{lc}
\hline PGPR traits & $\begin{array}{c}\text { Rhizobium } \\
\text { undicola strain N37 }\end{array}$ \\
\hline IAA production $(\mu \mathrm{g} / \mathrm{mL})$ & $55.0 \pm 0.33$ \\
ACC deaminase activity $(\mathrm{nmol}$ & $2334.2 \pm 2.90$ \\
$\alpha$-ketobutyrate $/ \mathrm{mg}$ protein $/ \mathrm{h})$ & $2.0 \pm 0.11$ \\
Phosphate solubilization $(\mathrm{mg} / \mathrm{L})$ & $68.0 \pm 2$ \\
Siderophore activity $(\%)$ & $132.0 \pm 3.05$ \\
EPS production $(\mu \mathrm{g} / \mathrm{mL})$ & $0.36 \pm 0.005$ \\
$\mathrm{~N}_{2}$ fixation $\left(\mu \mathrm{g} \mathrm{N}\right.$ fixed $\left.\mathrm{hr}^{-1}\right)$ & \\
\hline
\end{tabular}

acid also has strong antioxidative properties like flavonoids that helps to keep the metal ions such as $\mathrm{Mn}^{2+}$ and $\mathrm{Fe}^{3+}$ reduced and active state which acted as a cofactor of IAA oxidase and peroxidase, respectively, to stimulate IAA production [55].

3.6. PGP Traits of the Isolated Symbionts. The existence of ACC deaminase activity along with other characteristics like IAA production, EPS production, $\mathrm{N}_{2}$ fixation, phosphate solubilization, and siderophore production (Table 8) of this Rhizobium undicola isolated from Neptunia oleracea Lour. provided positive evidences for plant growth promotion (PGP). Siderophore chelated iron and other metals contributed to disease suppression by conferring a competitive advantage to biocontrol agents for the limited supply of essential trace minerals in natural habitats. ACC deaminase activity has also been reported from several other Rhizobium spp. strains [56]. ACC deaminase containing Rhizobium strain acts as a sink for ACC thereby lowering plant ethylene levels, releasing the inhibitory effect of root growth [57] and decreasing the negative effects of various environmental stresses [58]. ACC deaminase containing $R$. leguminosarum promoted nodulation of pea plants [59]. The expression of an exogenous ACC deaminase gene in Sinorhizobium meliloti increased its nodulation in alfalfa [60]. ACC deaminase containing PGPR reduced the ethylene levels which in turn was found to stimulate plant growth originally proposed by Glick et al. [61] which has also been reported in legumes by rhizobia $[59,60]$. The decrease in ethylene levels by ACC deaminase could reduce the plant stress responses and also relieves the ethylene repressed auxin responses factor (ARF) synthesis, indirectly leading to plant growth promotion that resulted from both stress alleviation and growth simulation [62, 63]. Therefore, Rhizobium (N37) with PGPR traits including ACC deaminase could facilitate plant growth by decreasing ethylene inhibition, promoting nodulation, permitting IAA stimulation, and reducing the physiological damage to plants by other environmental factors in this legume plant.

\section{Conclusions}

The present study concluded that the strain N37 isolated from root nodule of Neptunia oleracea Lour. was identified as Rhizobium undicola based on molecular phylogenetic approach. 
The higher level of IAA in nodules than roots might be due to the lower amount of IAA catabolising enzymes such as IAA oxidase and IAA peroxidase in nodules of this plant. Higher level of phenols in nodules than roots might have resulted from lower peroxidase and polyphenol oxidase activities in the nodules. ACC deaminase activity of Rhizobium undicola might promote nodulation, relieve the ethylene repressed auxin response factor (ARF) synthesis, and stimulate IAA accumulation. Thus, Rhizobium expressing ACC deaminase could promote infection by decreasing ethylene levels, stimulating IAA accumulation, and promoting plant growth along with other plant growth promoting rhizobacteria (PGPR) traits. The presence of significant amount of IAA catabolising enzyme in nodules, roots, and IAA synthesizing ability with other PGPR traits including ACC deaminase activity of symbiont might have physiological importance in plant microbes' interaction.

\section{Abbreviations}

IAA: Indole acetic acid

PGPR: Plant growth promoting rhizobacteria

LNB: Legume nodulating bacteria.

\section{Conflict of Interests}

The authors declare that there is no conflict of interests regarding the publication of this paper.

\section{Acknowledgment}

Financial support for Pallab Kumar Ghosh provided by University Grant Commission through Burdwan University is gratefully acknowledged.

\section{References}

[1] G. P. Lewis, B. D. Schrire, B. A. Mackinder, and J. M. Lock, Legumes of the World, Royal Botanic Gardens Kew, Richmond, VA, USA, 2005.

[2] J. I. Sprent, Legume Nodulation. A Global Perspective, WileyBlackwell, Chichester, UK, 2009.

[3] J. P. W. Young and K. E. Haukka, "Diversity and phylogeny of rhizobia," New Phytologist, vol. 133, no. 1, pp. 87-94, 1996.

[4] P. H. Graham, "Ecology of the root-nodule bacteria of legumes," in Nitrogen-fixing Leguminous Symbioses, M. J. Dilworth, E. K. James, J. I. Spent, and W. E. Newton, Eds., pp. 23-58, Springer, Dordrecht, The Netherlands, 2008.

[5] D. P. S. Verma, C.-A. Hu, and M. Zhang, "Root nodule development: origin, function and regulation of nodulin genes," Physiologia Plantarum, vol. 85, no. 2, pp. 253-265, 1992.

[6] G. J. Desbrosses and J. Stougaard, "Root nodulation: a paradigm for how plant-microbe symbiosis influences host developmental pathways," Cell Host \& Microbe, vol. 10, no. 4, pp. 348-358, 2011.

[7] W. J. Hunter, "Indole-3-acetic acid production by bacteroid from soyabean root nodules," Plant Physiology, vol. 76, no. 1, pp. 31-36, 1989

[8] C. Datta and P. S. Basu, "Indole acetic acid production by a Rhizobium species from root nodules of a leguminous shrub,
Cajanus cajan," Microbiological Research, vol. 155, no. 2, pp. 123127, 2000.

[9] S. Ghosh and P. S. Basu, "Production and metabolism of indole acetic acid in roots and root nodules of Phaseolus mungo," Microbiological Research, vol. 161, no. 4, pp. 362-366, 2006.

[10] P. K. Ghosh, P. Saha, S. Mayilraj, and T. K. Maiti, "Role of IAA metabolizing enzymes on production of IAA in root, nodule of Cajanus cajan and its PGP Rhizobium sp," Biocatalysis and Agricultural Biotechnology, vol. 2, no. 3, pp. 234-239, 2013.

[11] S. Spaepen, F. Das, E. Luyten, J. Michiels, and J. Vanderleyden, "Indole-3-acetic acid-regulated genes in Rhizobium etli CNPAF512: research Letter," FEMS Microbiology Letters, vol. 291, no. 2, pp. 195-200, 2009.

[12] C. Datta and P. S. Basu, "Content of indoleacetic acid and its metabolism in root nodules of Melilotus alba," Folia Microbiologica, vol. 43, no. 4, pp. 427-430, 1998.

[13] S. Ghosh, C. Sengupta, T. K. Maiti, and P. S. Basu, "Production of 3-indolylacetic acid in root nodules and culture by a Rhizobium species isolated from root nodules of the leguminous pulse Phaseolus mungo," Folia Microbiologica, vol. 53, no. 4, pp. 351355, 2008.

[14] S. Mandal, M. Mandal, A. Das, B. Pati, and A. Ghosh, "Stimulation of indoleacetic acid production in a Rhizobium isolate of Vigna mungo by root nodule phenolic acids," Archives of Microbiology, vol. 191, no. 4, pp. 389-393, 2009.

[15] B. K. Sinha and P. S. Basu, "Indole-3-acetic acid metabolism in root nodules of Pongamia pinnata (L.) pierre," Biochemie und Physiologie der Pflanzen, vol. 176, no. 3, pp. 218-227, 1981.

[16] A. C. Ghosh and P. S. Basu, "Indole acetic acid and its metabolism in the root nodules of a leguminous tree Dalbergia lanceolaria," Indian Journal of Experimental Biology, vol. 36, no. 10, pp. 1058-1060, 1998.

[17] M. Shridevi and K. V. Mallaiah, "Production of indole-3-acetic acid by Rhizobium isolates from Sesbania species," African Journal of Microbiology Research, vol. 1, no. 7, pp. 125-128, 2007.

[18] Y. Nakamura, A. Murakami, K. Koshimizu, and H. Ohigashi, "Identification of pheophorbide a and its related compounds as possible anti-tumor promoters in the leaves of Neptunia oleracea," Bioscience, Biotechnology and Biochemistry, vol. 60, no. 6, pp. 1028-1030, 1996.

[19] V. B. D. Skerman, A Guide to the Identification of the Genera of Bacteria with Methods and Digests of Generic Characteristics, The Williams and Wilkins, Baltimore, Md, USA, 1959.

[20] J. Sambrook and D. W. Russell, Molecular Cloning: a Laboratory Manual, Cold Spring Harbor Laboratory, Cold Spring Harbor, NY, USA, 3rd edition, 2001.

[21] M. Kimura, "A simple method for estimating evolutionary rates of base substitutions through comparative studies of nucleotide sequences," Journal of Molecular Evolution, vol. 16, no. 2, pp. 111120, 1980.

[22] T. Ezaki, Y. Hashimoto, and E. Yabuuchi, "Fluorometric deoxyribonucleic acid-deoxyribonucleic acid hybridization in microdilution wells as an alternative to membrane filter hybridization in which radioisotopes are used to determine genetic relatedness among bacterial strains," International Journal of Systematic Bacteriology, vol. 39, no. 3, pp. 224-229, 1989.

[23] P. K. Ghosh, J. Ganguly, P. Maji, and T. K. Maiti, "Production and composition of extracellular polysaccharide synthesized by Rhizobium undicola isolated from aquatic legume, Neptunia oleracea Lour," Proceedings of the National Academy of Sciences, India Section B: Biological Sciences, 2014. 
[24] S. A. Gordon and R. P. Weber, "Colorimetric estimation of indole acetic acid," Plant Physiology, vol. 26, no. 1, pp. 192-195, 1951.

[25] J. P. Nitsch, "Free auxin and free tryptophan in straw berry," Plant Physiology, vol. 30, pp. 33-39, 1955.

[26] S. S. M. Hassan, "New spectrophotometric method for simultaneous determination of tryptophan and tyrosine," Analytical Chemistry, vol. 47, no. 8, pp. 1429-1432, 1975.

[27] H. G. Bray and M. V. Thorpe, "Analysis of phenolic compounds of interest in metabolism," in Methods of Biochemical Analysis, D. Glick, Ed., vol. 1, pp. 17-52, Inter Science, New York, NY, USA, 1954.

[28] M. Kar and D. Mishra, "Catalase, peroxidase and polyphenol oxidase activities during rice leaf senescence," Plant Physiology, vol. 57, no. 2, pp. 315-319, 1976.

[29] O. H. Lowry, N. J. Rosebrough, A. L. Faar, and R. J. Randall, "Protein measurement with the Folin phenol reagent," The Journal of Biological Chemistry, vol. 193, no. 1, pp. 265-275, 1951.

[30] S. Mehta and C. S. Nautiyal, "An efficient method for qualitative screening of phosphate-solubilizing bacteria," Current Microbiology, vol. 43, no. 1, pp. 51-56, 2001.

[31] M. L. Jackson, Estimation of Phosphorus Content: Soil Chemical Analysis, Prentice Hall, New Delhi, India, 1973.

[32] B. Schwyn and J. B. Neilands, "Universal chemical assay for the detection and determination of siderophores," Analytical Biochemistry, vol. 160, no. 1, pp. 47-56, 1987.

[33] S. M. Payne, "Detection, isolation, and characterization of siderophores," Methods in Enzymology, vol. 235, pp. 329-344, 1994.

[34] B. D. Davis and E. S. Mingioli, "Mutants of Escherichia coli requiring methionine or vitamin $\mathrm{B}_{12}$," Journal of Bacteriology, vol. 60 , no. 1, pp. 17-28, 1950.

[35] J. D. Pagan, J. J. Child, W. R. Scowcroft, and A. H. Gibson, "Nitrogen fixation by Rhizobium cultured on a defined medium," Nature, vol. 256, no. 5516, pp. 406-407, 1975.

[36] J. L. N. Rao, I. C. Pasalu, and V. R. Rao, "Nitrogen fixation $\left(\mathrm{C}_{2} \mathrm{H}_{2}\right.$ reduction) in the rice rhizosphere soil as influenced by pesticides and methods of their application," The Journal of Agricultural Science, vol. 100, no. 03, pp. 637-642, 1983.

[37] M. Dubois, K. A. Gilles, J. K. Hamilton, P. A. Rebers, and F. Smith, "Colorimetric method for determination of sugars and related substances," Analytical Chemistry, vol. 28, no. 3, pp. 350356, 1956

[38] B. R. Glick, D. M. Karaturovic, and P. C. Newell, "A novel procedure for rapid isolation of plant growth promoting pseudomonads," Canadian Journal of Microbiology, vol. 41, no. 6, pp. 533-536, 1995.

[39] M. Honma and T. Shimomura, "Metabolism of 1-aminocyclopropane-1-carboxylic acid," Agricultural and Biological Chemistry, vol. 42, no. 10, pp. 1825-1831, 1978.

[40] J. H. Zar, Biostatistical Analysis, Pearson Education, Singapore, 4th edition, 1999.

[41] P. R. Kinnear and C. D. Gray, SPSS for Windows Made Simple, Release 10, Psychology Press, Sussex, UK, 2000.

[42] Y. Paisooksantivatana, "Neptunia oleracea Loureiro," in Plant Resources of South-East Asia No. 8: Vegetables, K. Piluek, Ed., pp. 217-218, Pudoc, Wageningen, The Netherlands, 1993.

[43] H. A. Stafford, "The metabolism of aromatic compounds," Annual Review of Plant Physiology, vol. 25, no. 1, pp. 459-486, 1974.
[44] C. P. Vance, "Comparative aspects of root and root nodule secondary metabolism in alfalfa," Phytochemistry, vol. 17, no. 11, pp. 1889-1891, 1978.

[45] R. Rivas, E. Velázquez, A. Willems et al., "A new species of Devosia that forms a unique nitrogen-fixing root-nodule symbiosis with the aquatic legume Neptunia natans (L.f.) Druce," Applied and Environmental Microbiology, vol. 68, no. 11, pp. 5217-5222, 2002.

[46] Y.-J. Chou, G. N. Elliott, E. K. James et al., "Labrys neptuniae sp. nov., isolated from root nodules of the aquatic legume Neptunia oleracea," International Journal of Systematic and Evolutionary Microbiology, vol. 57, no. 3, pp. 577-581, 2007.

[47] L. D. Kuykendall, F. B. Dazzo, L. F. De Lajudie, T. Willems, C. Coopman, and D. G. Kersters, "Allorhizobium," in The Proteobacteria: Bergey's Manual of Systematic Bacteriology, D. Brenner, N. Krieg, J. Staley, and G. Garrity, Eds., vol. 2, pp. 345346, Springer, New York, NY, USA, 2nd edition, 2005.

[48] D. C. Jordan, "Rhizobiaceae," in Bergey's Manual of Systematic Bacteriology, N. R. Krieg and J. G. Holt, Eds., vol. 1, pp. 234256, Williams and Wilkins Co., Baltimore, Md, USA, 1984.

[49] J. M. Vincent, "Root nodule symbiosis with Rhizobium," in The Biology of Nitrogen Fixation, pp. 265-341, North-Holland, Amsterdam, The Netherlands, 1974.

[50] S. Chakrabarti, M. S. Lee, and A. H. Gibson, "Diversity in the nutritional requirements of strains of various Rhizobium species," Soil Biology and Biochemistry, vol. 13, no. 5, pp. 349354, 1981.

[51] S. Ghosh, P. Ghosh, and T. K. Maiti, "Production and metabolism of indole acetic acid (IAA) by root nodule bacteria (Rhizobium): a review," Journal of Pure and Applied Microbiology, vol. 5, no. 2, pp. 523-540, 2011.

[52] E. Fedorova, F. J. Redondo, T. Koshiba, J. J. Pueyo, M. R. de Felipe, and M. M. Lucas, "Aldehyde oxidase (AO) in the root nodules of Lupinus albus and Medicago truncatula: Identification of AO in meristematic and infection zones," Molecular Plant-Microbe Interactions, vol. 18, no. 5, pp. 405-413, 2005.

[53] D. E. Brown, A. M. Rashotte, A. S. Murphy et al., "Flavonoids act as negative regulators of auxin transport in vivo in Arabidopsis," Plant Physiology, vol. 126, no. 2, pp. 524-535, 2001.

[54] D. Chakraborty and S. M. Mandal, "Fractional changes in phenolic acids composition in root nodules of Arachis hypogaea L," Plant Growth Regulation, vol. 55, no. 3, pp. 159-163, 2008.

[55] E. A. Schneider and F. Wightman, "Metabolism of auxin in higher plants," Annual Review of Plant Physiology, vol. 25, no. 1, pp. 487-513, 1974.

[56] W. Ma, S. B. Sebestianova, J. Sebestian, G. I. Burd, F. C. Guinel, and B. R. Glick, "Prevalence of 1-aminocyclopropane1-carboxylate deaminase in Rhizobium spp," Antonie van Leeuwenhoek, vol. 83, no. 3, pp. 285-291, 2003.

[57] M. Madhaiyan, S. Poonguzhali, J. Ryu, and T. Sa, "Regulation of ethylene levels in canola (Brassica campestris) by 1-aminocyclopropane-1-carboxylate deaminase-containing Methylobacterium fujisawaense," Planta, vol. 224, no. 2, pp. 268278, 2006.

[58] J. C. Stearns, S. Shah, B. M. Greenberg, D. G. Dixon, and B. R. Glick, "Tolerance of transgenic canola expressing 1aminocyclopropane-1-carboxylic acid deaminase to growth inhibition by nickel," Plant Physiology and Biochemistry, vol. 43, no. 7, pp. 701-708, 2005.

[59] W. Ma, F. C. Guinel, and B. R. Glick, "Rhizobium leguminosarum biovar viciae 1-aminocyclopropane-1-carboxylate deaminase 
promotes nodulation of pea plants," Applied and Environmental Microbiology, vol. 69, no. 8, pp. 4396-4402, 2003.

[60] W. Ma, T. C. Charles, and B. R. Glick, "Expression of an exogenous 1-aminocyclopropane-1-carboxylate deaminase gene in Sinorhizobium meliloti increases its ability to nodulate alfalfa," Applied and Environmental Microbiology, vol. 70, no. 10, pp. 5891-5897, 2004.

[61] B. R. Glick, D. M. Penrose, and J. Li, "A model for the lowering of plant ethylene concentrations by plant growth-promoting bacteria," Journal of Theoretical Biology, vol. 190, no. 1, pp. 63-68, 1998.

[62] N. Dharmasiri and M. Estelle, "Auxin signaling and regulated protein degradation," Trends in Plant Science, vol. 9, no. 6, pp. 302-308, 2004.

[63] B. R. Glick, B. Todorovic, J. Czarny, Z. Cheng, J. Duan, and B. McConkey, "Promotion of plant growth by bacterial ACC deaminase," Critical Reviews in Plant Sciences, vol. 26, no. 5-6, pp. 227-242, 2007. 

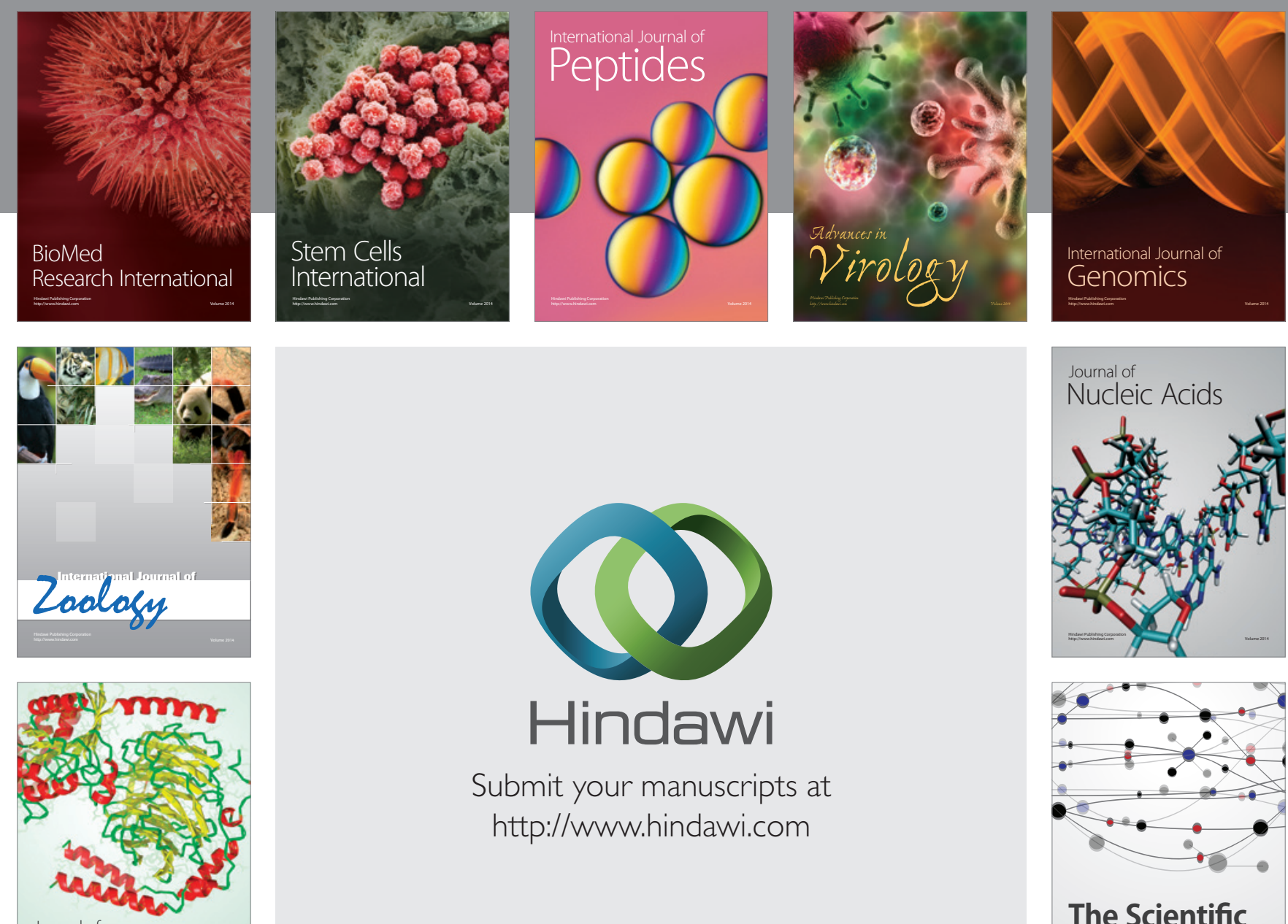

Submit your manuscripts at

http://www.hindawi.com

Journal of
Signal Transduction
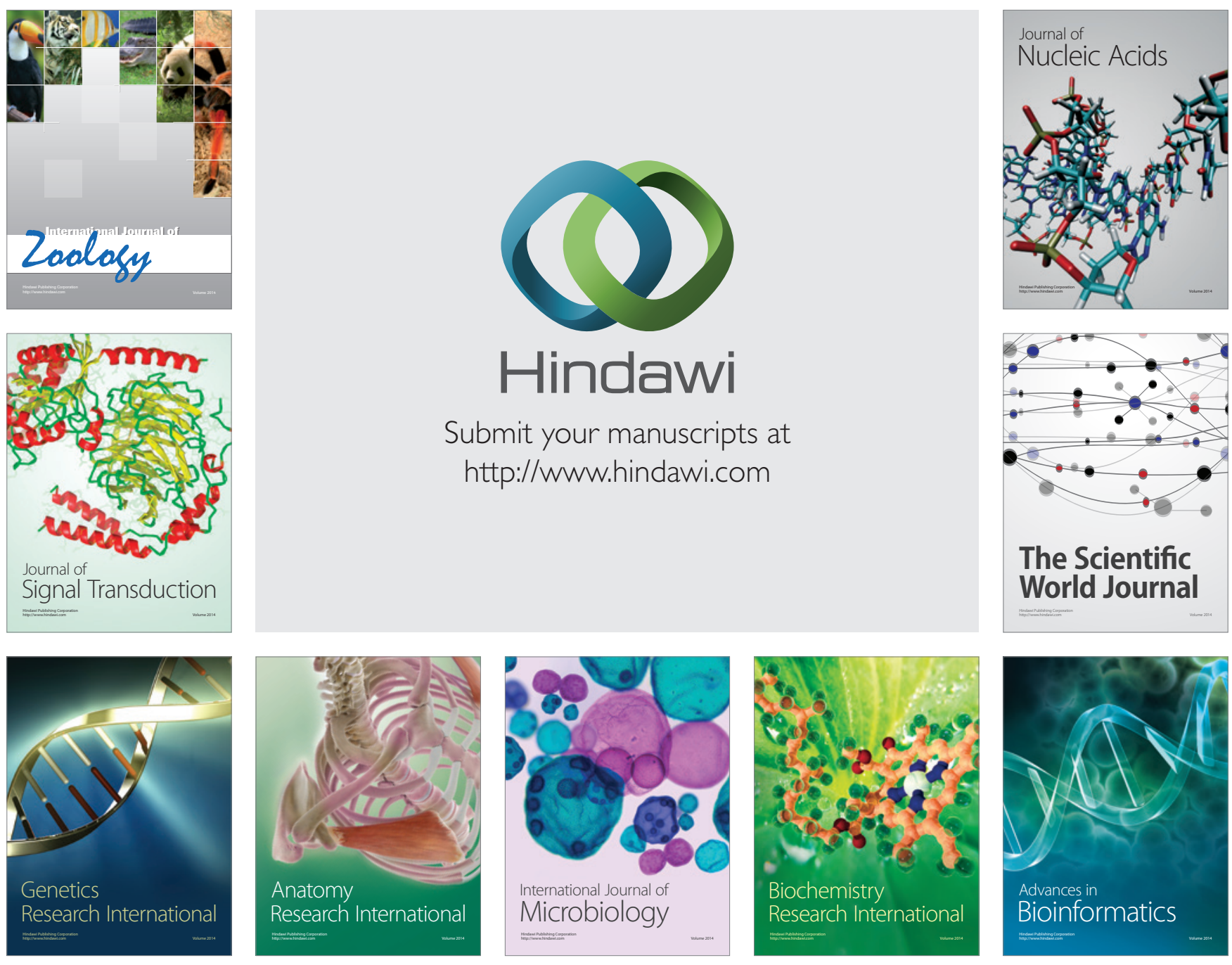

The Scientific World Journal
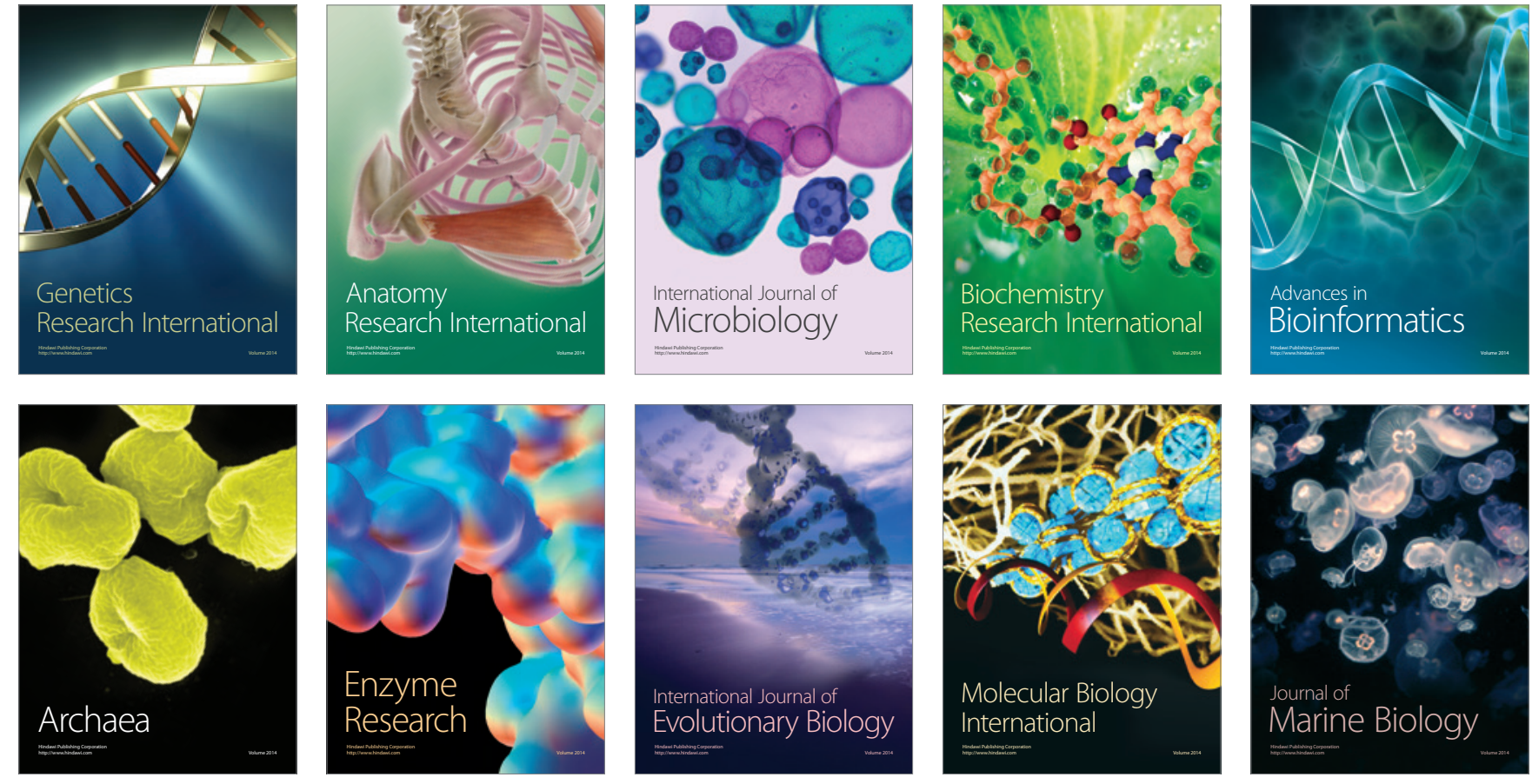